\title{
7. Indigenous Workers on Methodist Missions in Arnhem Land: A skilled labour force lost
}

\author{
Gwenda Baker
}

Indigenous workers on Methodist missions in Arnhem Land were not only vital to mission development and survival; over time, they became an increasingly skilled, competent and reliable workforce. By the end of the mission era, Indigenous participation in the economy of these missions led to an increased skill base amongst the majority of workers. Indigenous workers who remember life on the missions see the end of 'mission time' as the beginning of the end of full employment and participation in a 'real economy' and the hopes of Indigenous control over a new social order (Baker 2005, 2010). They were to be a skilled labour force lost.

Indigenous leaders talk about Indigenous achievements in 'mission time' in the face of current problems, including a generation of young people who have grown up without the example of a fully engaged Yolngu workforce. Reverend Dr Djiniyini Gondarra (2009) in his submission to the NT Government talks about the future of these children:

When we look around our communities today, we see all the work being done by dominant culture people... Our children want to know why they need to go to school when there is no role for them in our community. Our parents wonder what role or future our children have... it is very sad.

Leaders are seeking narratives and photographic evidence to support the stories they tell to their children and grandchildren. They also need these narratives to speak to a wider audience, telling of their fears for their children and the necessity for Indigenous labour to be the main workforce in their communities.

The stories Yolngu tell about their work on Methodist missions emphasise that mission establishment and development were joint enterprises between Indigenous participants and missionaries in Arnhem Land (Baker 2005). The Yolngu have repositioned the role of the early leaders in the creation of the missions in an attempt to take charge of narratives of mission development (Baker 2005). They tell stories of their fathers and grandfathers forming contracts with the missionaries and working together to establish the towns. 
One of these stories from a Wangurri clan leader tells about how his father participated in the founding of the mission on Elcho Island. Badanga was his father; Makarrwalla was Badanga's brother. They both travelled to Elcho Island from Milingimbi with the first missionary, Reverend Harold Shepherdson, to establish a new mission (Baker 2005). The story was told to me at Galiwin'ku, Elcho Island, in 1998:

The mission began when...Yolngu moved over to Elcho... They came to establish a town for themselves with the missionaries...There were smokes, food; jobs that got men to come here... Badanga and Makarrwalla went out and told the others about the town... They learnt about clothes, how to grow gardens, work hard to earn something in the future.

Rudder (1993:302) was told a similar story by the father of Djiniyini Gondarra, Golumala clan leader Willi Walalipa, who also travelled to Elcho Island on this first trip.

I lived on Methodist missions in Arnhem Land in the period 1968-71, and I witnessed the rapid growth of industries and the development of a skilled Indigenous labour force. My research reinforces my view that Indigenous people who pioneered mission development strove to develop working skills within the mission system. A close examination of government and mission documents reveals that a large number of industries were closed down and the workforce was drastically reduced by government action in the creation of award wage positions at the end of the mission era. The later uptake of social service benefits exacerbated the problems of creating a new Indigenous economy.

Indigenous writers identify these problems in stories of the decline of the Indigenous workforce in other areas. Pearson (2009:157-9) suggests that during the period of mission influence in the Cape York area the Indigenous economy, although operating at the lower end of the labour market, was a real economy. People had to work in order to be paid. There was a combination of work on the mission and off the mission. Pearson sees the introduction of the 'welfare economy' at the end of the mission era as the most destructive reason for the collapse of the Indigenous economy and the widespread social dislocation that followed. The 'welfare economy' was not a 'real economy' in that it required no social involvement or work to be paid. The nexus between work and reward was broken.

Trudgen (2000) addresses the long-term effects of white intervention in one of the areas of the operation of the Methodist missions in north-east Arnhem Land. In his book and in workshops run by Trudgen and Yolngu presenters for the Aboriginal Research and Development Services (ARDS), continuing problems of lack of communication and understanding of Yolngu ways are explored. There is 
a focus on the negative outcomes of white contact - the reduction in the power of leaders, the loss of power over Indigenous lives - and the effects of the drop in Indigenous employment opportunities and the introduction of a new, far more lethal 'welfare economy' of dependence and despair.

While acknowledging the damage of colonial incursion into their territory and the resultant disruption to their social and religious lives, Yolngu leaders also identify levels of local leadership, active learning situations, and gains and achievements during the mission era. In the mid-1950s, Indigenous builder Stephen Bunbaitjun and his team built a new school on Elcho Island. (Bunbaitjun is an old spelling of the name, as used by Stephen on his paintings. There are two new spellings of his name in current usage at Galiwin'ku: Bunbatjun and Bunbatju.) By the mid-1960s, Bunbaitjun had moved his group to Howard Island near Elcho Island, where he planned and built houses on his outstation (see Baker 2005:Figure 7.1). He sold his own bark paintings and watercolour paintings, mats and baskets made by the women and logs floated over to Elcho Island to help finance his building program. Reverend Peter O'Connor (2004), Mission Superintendent at Goulburn Island from 1967 to 1972, reported that by the 1970s Indigenous carpenters were skilled enough to build their own houses. The Goulburn Island mission tendered for and built a staff house on the nearby government settlement at Maningrida using Indigenous builders.

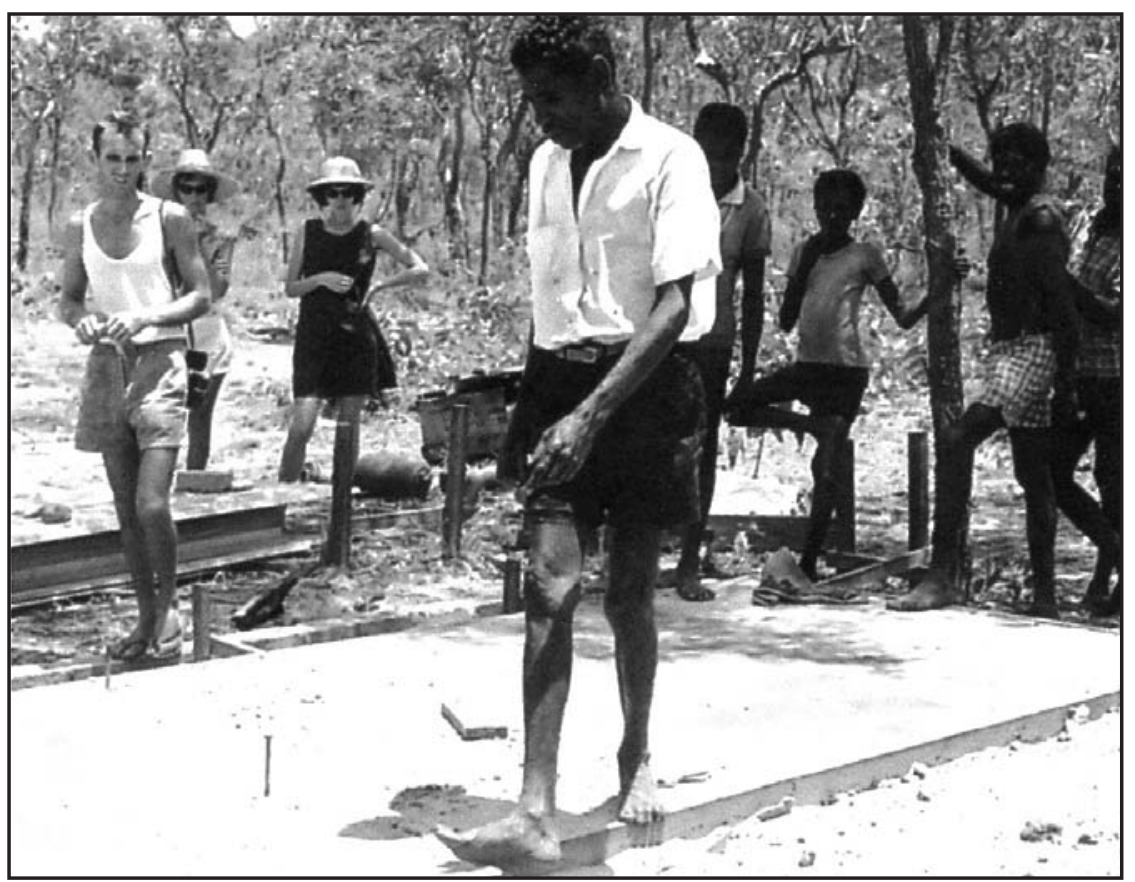

Figure 7.1 Stephen Bunbaitjun: Builder, Howard Island

Photo: Ivan Baker 
Missionary accounts about the effectiveness of the Indigenous workforce vary, but by the 1970s on Elcho Island and Goulburn Island the workforce was increasingly competent and many workers could and did work independently of mission supervision. At Elcho Island, Indigenous workers went out and cut and collected timber on the mainland and the islands with small gangs of men who worked unsupervised for several days at a time (Figure 7.2). Building was a priority and experienced workers could plan, set out and build houses with their own gangs and under minimal supervision.

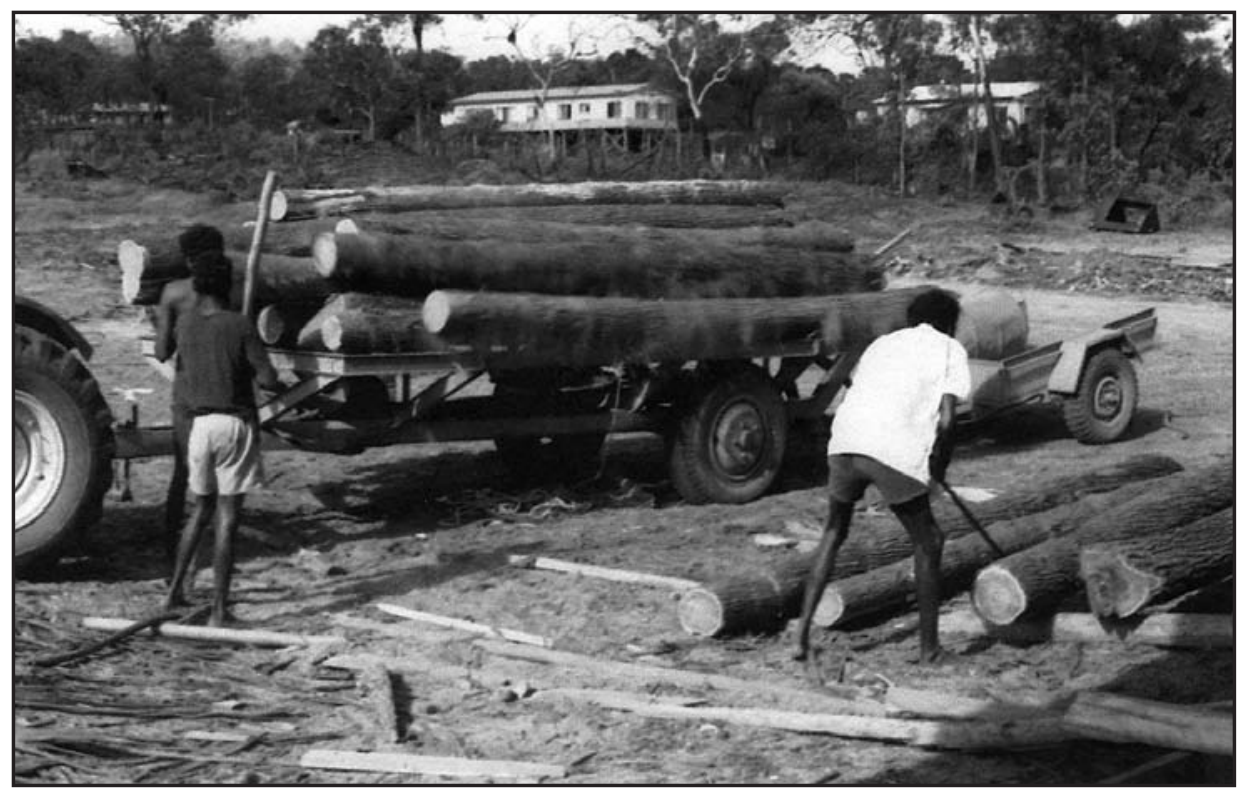

Figure 7.2 Unloading logs

Photo: Ivan Baker.

In an interview with Paul Myers (2010), Doug Miller, manager of Roebuck Plains, talked about helping to make Indigenous youths 'work ready', reinventing the place of the Indigenous stockman. The proponents of these worthwhile projects appear to be unaware that at the end of the mission era there was an Indigenous workforce that was more than 'work ready': it was a workforce that operated at a high level of competence and contributed greatly to the development, wellbeing and maintenance of new European-style towns. At the end of the mission era the Government took over the towns, dismantled the fledgling industries, rejected proposals for Indigenous-run enterprises and shrank an Aboriginal workforce that was building their own houses and buildings for community use and providing the workforce for the majority of town enterprises. 


\section{From Barter to Training Wages}

The Methodist Church established missions along the coast of Arnhem Land on Goulburn Island in 1916, on Milingimbi in 1923, at Yirrkala in 1935 and on Elcho Island in 1942 (Map 7.1). Missionaries were setting up towns and developing infrastructure in remote areas with inadequate financing from church and government sources. It was crucial to the mission venture for missionaries to elicit help from the Indigenous people either as unpaid or as paid workers. To do this, they sought and gained the cooperation of the Indigenous people who moved to the mission sites.

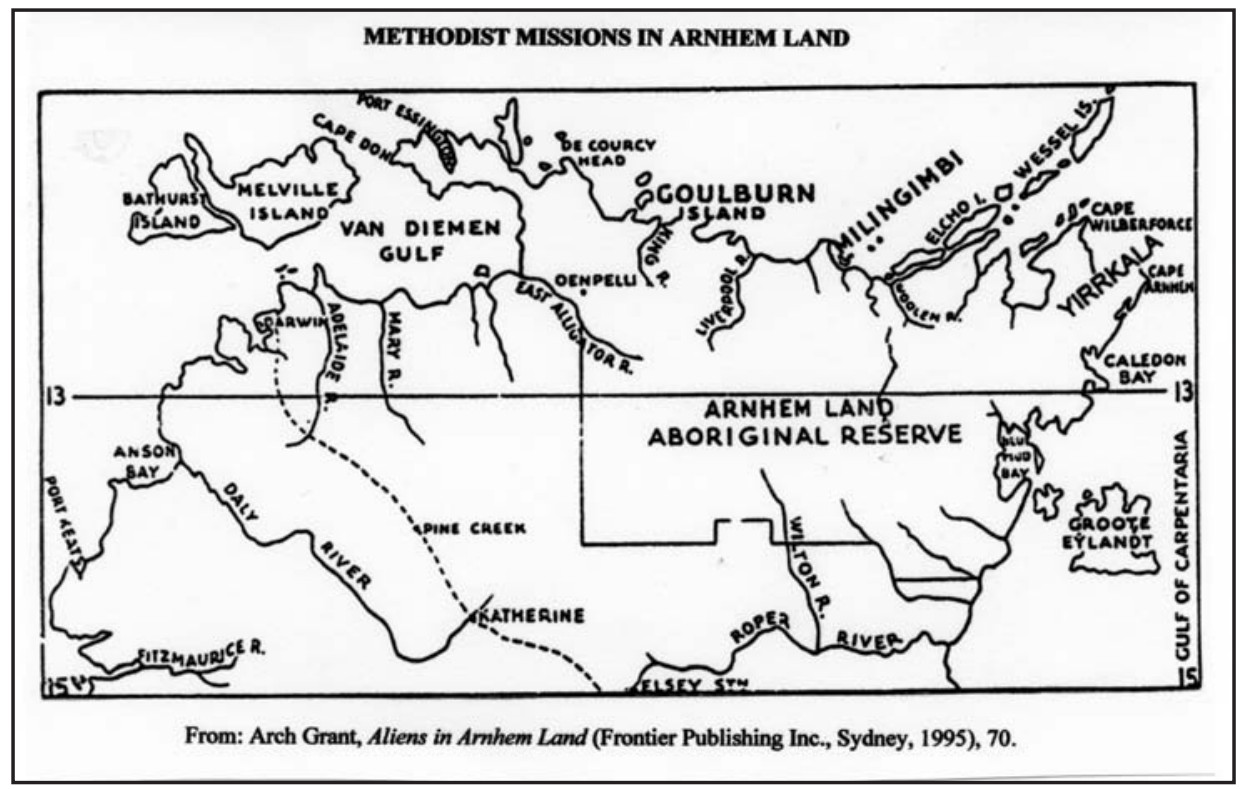

Map 7.1 Methodist missions in Arnhem Land

Source: Grant (1995:70).

Foundation Methodist missionary Ella Shepherdson (1981) wrote of the cooperation and contribution of Yolngu workers in mission development. In the only comprehensive account of the Methodist missions in Arnhem Land, Maisie MacKenzie (1976) evaluates the workload and enterprise of the missionaries above the contribution of the Indigenous population. The support of the local population is noted, and individuals praised for their contributions.

A barter economy operated in early transactions on and off Methodist missions for up to 20 years. Aborigines accepted food as payment for their labour and crocodile skins were exchanged for axes, flour, tobacco, cloth and tools. Ella Shepherdson (1981:36) explains: 'In those days there was no money available to pay people for work done on the [air] strips, only food and hand tools were 
supplied.' There were advantages for Aborigines who could remain off the mission while developing new skills and exchanging goods. For the missionaries, it was a way of existing without proper monetary support.

The change from barter trading to a cash economy came as a result of demands from Indigenous workers. Contact with the outside world intensified during the war years. Patrol officer Gordon Sweeney (1951) recorded the change, noting that 'Arnhem Land natives... are becoming more money conscious'. In 1950 at Elcho Island he had witnessed the arrival of a message stick from 'a group of natives' living in the Buckingham Bay area: 'Marks made on one half of the letter stick signified the two groups who were waiting and small circles on the other half signified money which they desired in payment.' He reported that when missionary Harold Shepherdson made the next trip to Buckingham Bay an exchange of money for skins took place (Sweeney 1951:6). He paid $£ 16$ to the 'head boys', who distributed the money to the other workers:

The trade goods were then unpacked from the aeroplane-flour, sugar, jam, tobacco, soap, matches, razor blades, combs, mirrors, billy cans, towels, shorts and skirts were spread out and the men came forward and made their purchases; following the men came their wives, who had also shared in the returns.

The 1950s brought changes to mission funding that would enable the mission societies to pay Indigenous workers. Paul Hasluck became Minister for Territories with Aboriginal Affairs as his responsibility. At the first Native Welfare Conference in 1951, he promoted a greater priority for government funding for Aborigines. From 1952 the new Welfare Branch reorganised mission funding, and biennial mission/administrative conferences dealt with policy issues including finance. With the new emphasis on the Aborigine as an individual and with increased demands for welfare and training, the Church renewed its claim for increased funding. ${ }^{1}$

The Wards' Employment Ordinance of 1953 undertook to provide more protection for Aboriginal workers (classified in the legislation as 'wards'). The Employment Advisory Board was to be established with only one Aboriginal representative and that had to be a non-ward. Provisions were set down for training, employment and assistance to wards. The director decided the suitability of wards for training and the type of training they would receive. Employers could be given permission under licence to employ wards as apprentices. General employers of wards were also licensed. Welfare officers could inspect the workplaces of wards and licences could be cancelled. Part of the ward's

1 Letter from C. F. Gribble, Chairman, Methodist Overseas Mission [hereinafter MOM], to the Administrator, 17 September 1952, CRS F1/0, 1952/645, National Archives Australia (Northern Territory) [hereinafter NAA (NT)]. 
wage could go into a trust fund administered by the director. The Ordinance specified that on missions, trading posts could be established to 'enable wards to buy, sell or barter articles'.

In its practical application, the Wards' Employment Ordinance of 1953 was to provide little assistance to Aboriginal workers on missions and reserves. Peterson (1998:107) argues that the legislation that determined that Aborigines were wards whilst on missions and reserves actually led to a situation where Aboriginal workers were confined and therefore disadvantaged. The Ordinance did not come into effect until the Aboriginal Register had been completed in 1959. In 1960 missions and government settlements applied for exemption from the provisions of the Ordinance on the grounds that they were not employers in the strictest sense but providers of social welfare and training. ${ }^{2}$ In 1962 the Commonwealth Government accepted the missions' proposal. $^{3}$ In 1962 an amendment to the Commonwealth Electoral Act enfranchised all Aboriginal adults with the resultant anomaly that Aborigines were officially citizens without the right to equal wages.

By 1963 changes to the Wards' Employment Ordinance made the Crown (and therefore government settlements) subject to the provisions of the Ordinance, and the missions could no longer claim special exemption. The Department of Territories advised the minister that it was a 'matter of natural justice' for Aboriginal workers on missions to 'have the same opportunities and scope for training and advancement as other Aboriginal workers in the Territory' ${ }^{4}$ It noted that

Aboriginals employed on missions constitute roughly $1 / 3$ of the aboriginal labour force in the Northern Territory and as long as their conditions are not up to the standards of Aborigines employed in outside industry and on Government settlements, their employment is a potential source of discontent among the Aboriginal people themselves and a potential target for the political critics of policy. ${ }^{5}$

The Social Welfare Ordinance of 1964 removed restrictions under the 1957 Ordinance except the power of the NT administration to control wages and access to reserves.

Criticism of government policy came from diverse groups such as the Communist Party, the Australian Board of Missions and the Federal Council for the

\footnotetext{
2 Application Wards' Employment Ordinance, Department of Territories, Paper on Memorandum 61/605 [12 June 1963], CRS E460/51, 74/718, NAA (NT).

3 Letter, Secretary, Department of Territories, C. R. Lambert, to Administrator of the Northern Territory [19 February 1962], CRS E460/51, 74/718, NAA (NT).

4 Paper on Memorandum 61/605 [12 June 1963], CRS E460/51, 74/718, NAA (NT).

5 Ibid.
} 
Advancement of Aboriginal and Torres Straight Islanders, which argued for equal wages for Aborigines on the basis of their status as Australian citizens recently given the right to vote. In 1966 the Conciliation and Arbitration Commission agreed to delete the clauses in the Social Welfare Ordinance that had excluded Aboriginal workers from the Cattle Station (Northern Territory) Award. They would be given full pay but the date for full implementation was deferred until December 1968. This put pressure on mission societies to match the wage expectations of Aboriginal workers on missions. In 1968 the annual Northern District Synod petitioned the Social Welfare Branch over the disparity between mission wages and the proposed new wages for Aboriginal workers on pastoral properties. The missions would be unable 'to make substantial wage increases establishing equality' and the synod requested that the Social Welfare Branch 'increase subsidies for industries and community services on Mission stations' ${ }^{6}$

From 1951 until the introduction of the government-funded Training Wages Scheme in 1969, the Church Synod set rates of pay. In 1954 the government subsidy for each missionary worker (male and female) was $£ 750 .^{7}$ From this subsidy the mission paid a sliding scale of wages to married male missionaries, single male missionaries and single female missionaries. ${ }^{8}$ MacKenzie (1976) recorded that the rest of the subsidy money was used to finance more mission employees and to pay Indigenous workers.

Contract labour allowed for a variety of payment schedules: piece work and hourly rates of pay; in later years there were more weekly rates of pay. While it suited the mission to have some permanent employees, the flexibility of contract work allowed for more Indigenous participants in the workforce. From the mid-1950s, the mixture of contract and weekly schedules appears in the mission wage schedules. The jobs available to Indigenous men included painting and woodwork, sawmilling, carpentry, electrical work, mechanical work, agriculture, hygiene, boat crews and teaching. Indigenous women were employed as house girls, as seamstresses and cooks, with teaching and nursing as the most prestigious occupations.

An apprenticeship scheme approved at the 1962 Synod proposed a five-year training program for fitters and turners, motor mechanics, electricians, carpenters and joiners, boat builders and cabinet-makers. ${ }^{9}$ By the mid-1960s, following a significant increase in government subsidies, apprenticeship schemes were set

6 Synod Report [1968], 52, 37.1.14, Northern Territory Archives Service [hereinafter NTAS].

7 Welfare Branch Correspondence [1948-62], Financial Assistance to Missions in the Northern Territory, 40,

9.14.1, NTAS. Letter from Acting Director of Native Affairs, R. K. McCaffery, to Rev. G. Symons, Chairman

North Australia District, MOM, Darwin [10 March 1954].

8 Board Minutes [1951-53], 343, MOM.

9 Synod Report [1961-62], 52, 37.1.5, NTAS. 
up on the missions. In a personal interview I conducted with Ruth Bray (1992), she talked about how most apprenticing of Aboriginal workers was done in an ad-hoc manner, using the available missionaries to school their workers. By the late 1960s, many workers had completed nursing and teaching training courses in Darwin after basic training on the missions.

Older Aboriginal men and women who remember life on the missions now comment on how they were paid low wages or no wages, or how they were given small amounts of food in lieu of wages for their labour. In an interview I conducted in 2006 with Daisy Dhulwatji (1) and Mangalalil (1), they talked about working as children for little money or for sugar as a reward. When wages were paid, missions estimated the value of rations and housing, power and water, which were supplied to Indigenous workers living on the missions, and this amount was deducted from their wages. From 1965, wages were paid in cash only, with no rations.

To make a comparison between wages for Indigenous mission workers and wages for other Australian workers, I have used male wage rates, as female Indigenous wages are not as highly represented in mission wage schedules. As with female mission workers, female Indigenous wages were less than male wages. The male wage rates for Indigenous mission workers is taken from the highest-paid jobs employing the greatest number of people: carpenters, painters, sawmillers, boat builders, mechanics, drivers, teaching assistants, agricultural/pastoral workers (Table 7.1). ${ }^{10}$

Table 7.1 Indigenous Male Mission Wages as a Percentage of the Commonwealth Male Basic Wage

\begin{tabular}{c|c}
\hline Year & Percentage of basic wage \\
\hline 1951 & 17 \\
\hline 1961 & 19 \\
\hline 1964 & 47 \\
\hline 1966 & 42 \\
\hline 1968 & 49 \\
\hline 1969 & 78 \\
\hline
\end{tabular}

\section{From Training Wages to Award Wages}

The first stage of award-wage implementation came with the 1969 Employment Training Scheme for Aborigines. The 'Training Allowance Scheme' designed

10 ABS (1960-65, 1962, 1966-73, 1968, 1970); 52, 37.1.3, NTAS; CRS F1: 54/80 and CRS E460: 75/544, NAA (NT). 
specifically for Aborigines on settlements was introduced a month later. The movement from a 'managed consumption' model to cash wages and social service payments exposed a divide between old and new missionaries. To older missionaries, the expansion of the moneyed economy would bring temptation and little satisfaction. Ella Shepherdson (1981:108) commented that 'a sudden influx of money did not bring happiness'. To younger staff, 'training wages' were pitifully low and the type of work perpetuated on the missions was demeaning. The difference between wages and conditions on and off the missions was becoming more transparent to those Aboriginal workers who had received training and worked in other locations for better wages. Reverend Brad Harris expressed these concerns in a series of letters to the Chairman of the Northern District, Reverend Gordon Symons:

The training allowance arrangements still fail to provide a sufficient living income, still fail to provide workers at management level, and still fail to provide enough work. Many...know very well that they are cheap labour doing work white people don't do. This is especially true where workers have had long experience or even training for a job... they are painfully aware that what they got as a driver, carpenter, plant operator or even labourer in Darwin or elsewhere in the Territory has no relation to what they get at Milingimbi. ${ }^{11}$

From 1 December 1973, award wages were introduced for Aborigines on missions and settlements. ${ }^{12}$ 'Training' positions and 'unproductive' jobs would be abolished, including many positions occupied by women. Married women would not be eligible for unemployment benefits. ${ }^{13}$ The department calculated that the workforce would reduce by one-third under the awards scheme, although in fact, as Peterson (1998:108) reported, it would be a two-thirds reduction. ${ }^{14}$ The missions had warned that this would be the possible outcome of the savage cut of jobs deemed to be 'unviable' under the Commonwealth Government's appraisal of mission-based work.

Award-wage implementation was already in progress when meetings with Aboriginal communities began. In 1974 an inter-departmental committee was

11 Letter from Rev. E. Bradley Harris to Rev. Gordon Symons [13 July 1972], Milingimbi Correspondence [1960-73], 40, 8.1.1, NTAS.

12 Introduction Award Wages to Aboriginal Communities in the Northern Territory, Copy 68, Decision 1534 [5 November 1973], Submission to Minister for Aboriginal Affairs Mr J. L. Cavanagh, CRS E460/51:74/695, NAA (NT).

13 Report on Meeting of Inter-Departmental Committee on Abolition of the Training Allowance Scheme in the Northern Territory, Canberra, [29 March 1974], CRS E460/51:74/542, NAA (NT).

14 Termination of Training Allowances and Introduction of Award Wages, Telex from ABAUS Darwin to ABAUS Canberra [23 May 1974], CRS E460/51: 74/1199, NAA (NT). 
formed to look at the possibility of alternative schemes of payment and the social distribution of money. Project consultative teams set up to visit communities were advised:

In many Aboriginal communities the impact of an award wage economy similar to that in urban Australia, together with unemployment benefits, could be unnecessarily disruptive of traditional life styles. In some areas, award wage structures will be appropriate and acceptable to the community, but in a community within its own understanding of its goals. The principle function of the teams should be to present and stimulate community consideration of alternative methods. ${ }^{15}$

The Government apparently did not regard Aborigines as citizens in the same economy, or sharing the values of other Australian citizens.

Town councils petitioned the Government to take heed of their concerns. Milingimbi Town Council urged the Government to recognise the conditions that had historically placed Aboriginal people living on missions in a unique position:

Aboriginal people want an opportunity to earn wages within their community. The government should be made aware of the stress and hardship, which would prevail if employment is lacking. Aboriginal people now firmly accept the money system and it is quite impractical for them to break away from it and return fully or in part to a tribal economy. ${ }^{16}$

The council saw problems if 'non-productive' jobs such as those of administrative workers, service staff and adult literacy were not funded and if more awardwage positions were not approved. The council complained about delays in government financial assistance for Aboriginal companies to run work-based enterprises on the stations, the loss of community members forced to seek work elsewhere, the plight of less than skilled workers, and the possibilities for social disruption from the loss of waged positions and unfunded economic enterprises resulting in a 'substantial move towards unemployment benefits'.

The House of Representatives Standing Committee on Aboriginal Affairs, which visited Yirrkala in 1974, stated that award wages would mean that 'those employed will be properly reimbursed for their labours and fewer people will be engaged on meaningless and demeaning tasks'. The payment of unemployment

15 Report on Meeting of Inter-Departmental Committee [29 March 1974] 104, CRS E460/51: 74/542, NAA (NT).

16 Review of Training Allowances and Progression to Award Level Wages, Letter from Milingimbi Council to Mr Shurmer, Department of Aboriginal Affairs [hereinafter DAA], Darwin [1 March 1974], CRS E460/51: 74/1838, NAA (NT). 
benefits would, however, 'aggravate an already serious drinking problem' and make it 'difficult to introduce alternative employment schemes'. The committee suggested extending the 'phasing in period' indefinitely. ${ }^{17}$ The committee appeared to be suggesting that 'meaningless work' would continue without 'proper reimbursement' indefinitely.

On the Maningrida government settlement in western Arnhem Land, CEO, Reverend Peter O'Connor (2004), former Mission Superintendent at nearby Goulburn Island, reprised the mission model of contract work:

Officials questioned why we never had anyone on the dole...Our way was simply that every person on our workforce worked on an hourly basis and attended for as many hours as they wished. In this way we spread our employment budget over a much larger group of people, as the average employee wished to work only twenty hours a week. Our way proved to be more desirable and rewarding than to arrange working for the dole as was applied in later years.

The future of work, funding and wages could not be resolved in the short period allotted for consultation. Mission negotiations resulted in the creation of additional award-wage positions, additional money for a continuation of training allowances and an extension in the timetable for the transition to award wages. ${ }^{18}$ By November 1974, both training allowance payments and special interim grants had been terminated. ${ }^{19}$

\section{Aftermath}

The period of transition, at the end of mission time, is now seen by the community leaders as a government takeover, not the assumption of Indigenous control. At the end of the mission era, the Government shut the existing industries without replacing them. Artist Peter Datjin Burarrwanga (2006) was working as a fisherman at the time. He talked about the shutdown of the large-scale fishing enterprise, which exported half their catch to Darwin, when the Government revoked their fishing licence. 'They ran out of licence, fishing licence... When they stopped the fisherman: get the boat back, get the net back, everything back. They took the big boat back, the fishing boat... when the government took this township from

17 House of Representatives Standing Committee on Aboriginal Affairs, Letter to Minister J. L. Cavanagh [20 March 1974], CRS E460/51: 74/1838, NAA (NT).

18 Copy 68, Submission to Mr J. L. Cavanagh, CRS E460/51: 74/695, NAA (NT); Abolition of Training Allowances, from B. G. Dexter to the Minister, DAA No. 1478 68/389, NT [6 June 1974], CRS E460/51: 74/542, NAA (NT).

19 New Employment Arrangements in Settlement and Mission Communities, Letter, I. Pitman to Regional Officer, DAA Alice Springs [1 November 1974], CRS E460/51: 74/695, NAA (NT). 
the mission.' The transition from fledgling training schemes to a proper industrybased system was never realised. White workers now fill most jobs with no sense of Aboriginal ownership in the work of the towns.

The transition from mission governance introduced a period of instability and a general decline in work practices. Reverend Dr Djiniyini Gondarra (2009) commented on how the people built their own houses during the time of the mission and the effect of changes to the work environment after the mission. His assessment of the collapse of the Indigenous economy after the mission era includes a story about how the Indigenous builders disappeared:

Here's one story about housing. We were building our houses on a contract basis until it was decided by the then Aboriginal Development Commission (ADC) that we were not building enough houses each year. ADC was concerned about their construction statistics, so the ADC started letting contracts to outside builders. People in the community saw that the outsiders were building pre-cut houses much faster than our own people so they began to question the skills and speed of our own people. Within a year, our Yolngu builders and tradesmen had put down their tools and said, 'Well if the Government wants to shame us in front of our people, then they can build all the houses'. These men walked away in shame even though the cost of their completed houses was under that of the Balanda [white] contractors. The Balanda had won again. When we look around our communities today, we see all the work being done by dominant culture people.

The change from a close working relationship with the missionaries to working with transient government workers contributed to this outcome. The Government did not understand the principles and concerns of Indigenous workers; and Indigenous leaders were now nominally in charge of a system that they did not have full control over.

Ian Keen noted in a conference response (Keen 2009) that in the mid-1970s, at the time when the regime was changing, there was a general lack of interest in work amongst the Yolngu at Milingimbi. This is reflected in a letter from missionary A. Baker in 1973 to Djawa, Town Council President at Milingimbi. It illustrates the kind of operational problems associated with the hand over to Aboriginal control:

Tomorrow the barge will come in and on that barge is food and other things for the people of Milingimbi. AS YET I DON'T KNOW WHO IS GOING TO UNLOAD THE GEAR BECAUSE THE PEOPLE THAT SHOULD DO IT, THE WORKS TEAM, DO NOT SEEM VERY INTERESTED IN IT, PERHAPS THE MOST IMPORTANT PART OF THEIR WORK. I cannot 
unload the barge by myself and will not try. All of the Balanda could unload it but will not because in this time of self-determination Aboriginal people make decisions AND do the work coming from those decisions. ${ }^{20}$

Indigenous leaders also associate the government takeover of the missions and the decline in work practices as part of the control mechanisms of the welfare economy. Reverend Dr Djiniyini Gondarra (2009) speaks of the various white invasions of their land:

Yolngu have always lived with this land. In recent times an invasion took place in this country... Since that time many foreigners have come to north-east Arnhem Land; with missions and welfare, with the police, with the mines. Each time we have lost more of our spirit and our identity.

Gondarra looks back to the achievements of the mission era and the way in which the Yolngu worked to build new communities:

Yolngu are strong people though and even after all these things and changes, we worked hard and rebuilt our communities in the Balanda way so that in the 1970s we were: building all our own housing; doing all our own road works; carrying out most of the office work; involved to a high level in...essential services; involved in...provision of health and education.

There was a sense of empowerment through employment and a real sense of ownership in the towns. It would seem that the current situation of low Indigenous employment and the lack of control over the running of the towns as they are now constituted in Arnhem Land has intensified and shaped this memory.

Recent Federal Government intervention policies and practices and the removal of community councils as administrative bodies are seen as more attacks on Indigenous control over local affairs. On Elcho Island, the Galiwin'ku Community Council is no longer the organising body for the town. The newly constituted East Arnhem Land Shire Council includes local representatives, but its administrative jurisdiction is much larger. The establishment of Community Advisory Committees, which report to the people and to the shire council, mitigates but does not remove a feeling of lack of control over local activities.

20 Town Council and Public Meetings, Baker, A. (1973) to Djawa, Town Council President at Milingimbi [5 December 1973], 40, 11.39.3, NTAS. 


\section{Conclusion}

Indigenous leaders now tell the story of 'mission time' as a period of exceptional Indigenous enterprise and involvement. Indigenous labour was both essential and effective in the process of mission development, and as the missions grew and training improved, the skill level of Aboriginal workers increased. By the end of the mission era there was high Aboriginal employment and involvement in the work of the community. In its haste to achieve wage parity with other Australian workers by moving to an award-wages scheme, the Government abandoned training schemes, emerging industries and flexible work arrangements. It was unable to address the problems of the unusual circumstances of an isolated, artificially constructed workforce or contemplate flexibility on the question of appropriate work and wage structures. Indigenous workers rightly questioned the likely outcomes of the new government model, but their input into the plans for their future went unheeded. They were a skilled labour force lost.

\section{References}

Aboriginal Ordinance Northern Territory of Australia Wards' Employment Ordinance No. 24 of 1953.

Aboriginal Ordinance Northern Territory of Australia No. 2 of 1957.

Aboriginal Ordinance Northern Territory of Australia Wards' Employment Ordinance No. 6 of 1959.

Aboriginal Ordinance Northern Territory of Australia Wards' Employment Ordinance No. 2 of 1961.

Aboriginal Ordinance Northern Territory of Australia Wards' Employment Ordinance No. 2 of 1963.

Australian Bureau of Statistics (ABS) 1960-65, 1966-73. Northern Territory, Statistical Summary 1-6. Canberra: Australian Bureau of Statistics.

Australian Bureau of Statistics (ABS) 1962. Year Book of Australia. No. 48 of 1962. Canberra: Australian Bureau of Statistics.

Australian Bureau of Statistics (ABS) 1968. Year Book of Australia. No. 54 of 1968. Canberra: Australian Bureau of Statistics.

Australian Bureau of Statistics (ABS) 1970. Year Book of Australia. No. 56 of 1970. Canberra: Australian Bureau of Statistics. 
Indigenous Participation in Australian Economies II

Baker, G. 2005. Crossing boundaries: negotiated space and the construction of narratives of missionary incursion. Journal of Northern Territory History 16: 17-28.

Baker, G. 2010. We just cry for our country: 'the boycott' and the Goulburn Islanders. Australian Historical Studies 41 (3): 302-18.

Bray, R. 1992. Life on the missions. Interview with Gwenda Baker, 31 July 1992, Melbourne.

Burarrwanga, P. D. 2006. Remembering 'mission time'. Interview with Gwenda Baker, 5 June 2006, Galiwin'ku, NT.

Dhulwatji, D. (1) and Mangalalil (1) 2006. Remembering 'mission time'. Interview with Gwenda Baker, 1 June 2006, Galiwin'ku, NT. Nancy Manurr Dhurrkay (interpreter).

Gondarra, D. 2009. Submission to Territory 2030. <http://www.ards.com.au>

Grant, A. 1995. Aliens in Arnhem Land. Sydney: Frontier Publishing.

Keen, I. 2009. Respondent to paper by Baker, G., 'From barter to award wages: Aboriginal labour on Methodist missions in Arnhem Land'. Indigenous Participation in Australian Economies Conference, National Museum of Australia, Canberra, 9-10 November 2009. <http://www.nma.gov.au/audio/ search/all/query:gwenda+baker>

MacKenzie, M. 1976. Mission to Arnhem Land. Adelaide: Rigby.

Methodist Church of Australasia n.d. Methodist Overseas Mission [MOM]. MOM 343, Mitchell Library, Sydney.

Myers, P. 2010. New wave. The Weekend Australian, 30-31 January: 12-15.

National Archives Australia (Northern Territory) Darwin: CRS E460/51: 74/542; CRS E460/51: 74/544; CRS E460/51: 74/695; CRS E460/51: 74/718; CRS E460/51: 74/1838; CRS F1 54/80 MOM-Elcho Island [1950-55]; CRS F1/0 1952/645 MOM Funding [1951-53].

Native Welfare in Australia. Report on the 1951 and 1952 Native Welfare Conference.

Northern Territory Archives Service, Darwin: 40 Milingimbi Township; 40 8.1.1; 40 9.14.1; 40 11.39.3; 52 37.1.1 Synod Reports [1946, 1947, 1948, 1949, 1951, 1952, 1952]; 52 37.1.2 Synod Reports [1953, 1954, 1955, 1956, 1957, 1958, 1959]; 52 37.1.3 Synod Report [1959-60]; 52 37.1.4 Synod Report [1960-61]; 52 37.1.5 Synod Report [1961-62]; 52 37.1.6 Synod Report [1962-63]; 52 37.1.7 Synod Report [1964]; 52 37.1.8 Synod Report [1965]; 52 37.1.9 Synod Report [1966]; 52 37.1.11 Synod Report [1967]; 52 37.1.12 Synod Report [1967]; 52 37.1.14 Synod Report [1968]; 52 37.1.15 Synod Report [1968-69]; 52 37.1.17 Synod Report [1969-70]. 
O'Connor, P. 2004. Unpublished memoirs. Brisbane.

Pearson, N. 2009. Up From the Mission. Melbourne: Black Inc.

Peterson, N. 1998. Welfare colonialism and citizenship: politics, economics and agency. In N. Peterson and W. Sanders (eds), Citizenship and Indigenous Australians: Changing conceptions and possibilities, pp. 101-17. Cambridge: Cambridge University Press.

Rudder, J. 1993. Yolngu cosmology: an unchanging cosmos incorporating a rapidly changing world? Unpublished PhD thesis, Australian National University, Canberra.

Shepherdson, E. 1981. Half a Century in Arnhem Land. Adelaide: One Tree Hill.

Social Welfare Ordinance No. 31 of 1964.

Sweeney, G. 1951. An experiment in a mission trading outpost. The Missionary Review 59 (7).

Trudgen, R. 2000. Why Warriors Lie Down and Die: Towards an understanding of why the Aboriginal people of Arnhem Land face the greatest crisis in health and education since European contact. Darwin: Aboriginal Resource and Development Services Incorporated. 